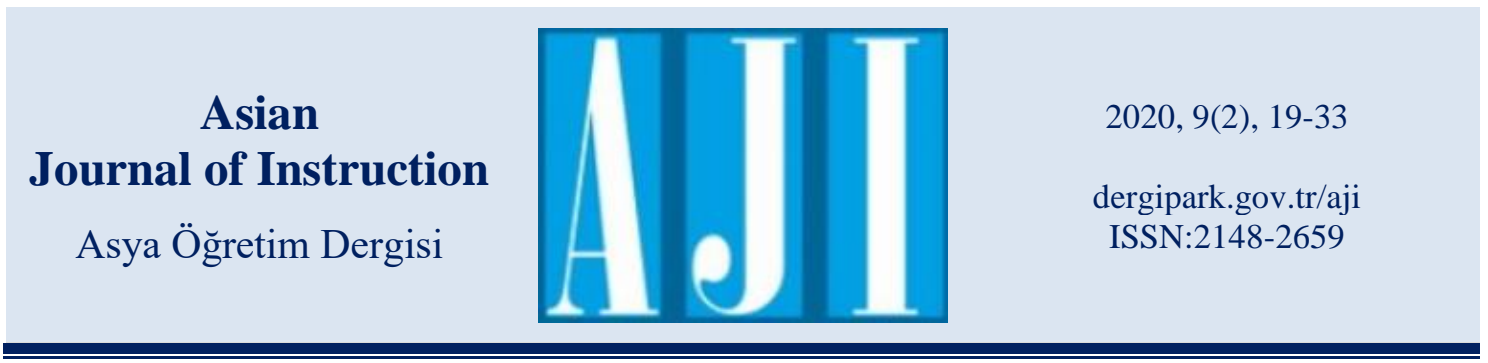

Geliş Tarihi: 05/05/2021

\title{
Devlet Okullarında Görev Yapan Öğretmenlerin Çocuklarını Özel Okullara Kayıt Yaptırmasının Nedenleri
}

\author{
Abdulsamet Kurban ${ }^{1}$ \\ Kurban, A. (2021). Devlet okullarında görev yapan öğretmenlerin çocuklarını özel okullara kayıt yaptırmasının \\ nedenleri. Asian Journal of Instruction, 9(2), 19-33. https://doi.org/10.47215/aji.933354
}

\section{$\ddot{O} \mathbf{z}$}

Toplumda yaşanan değişimler ve gelişmeler ailelerin eğitime bakış açısıını şekillendirmektedir. Bilgi çağı olarak adlandırılan günümüzde eğitimin değeri anlaşılmış, aileler çocuklarının eğitimi konusunda sorgulayıcı, araştırıcı ve seçici olmuşlardır. Eğitimin fiziksel, sosyal, bedensel ve zihinsel becerilere yönelik katkısı dikkat çeken bir unsur olmuştur. Bu nedenle aileler okul seçimlerini yaparken nitelikli okul arayışına girmişlerdir. Bu konudaki arayışlar, özel okulların alternatif olarak değerlendirmesine neden olmuştur. MEB'e bağlı olarak faaliyet gösteren devlet ve özel okul türleri; başarı, etkililik ve verimlilik açısından birbirinden farklılıklar göstermektedir. Bu farklılıklar, velilerin okul seçimi yaparken tercihlerini etkilemektedir. Özellikle okul seçiminde sınıf mevcudu, okulun teknolojik olanakları, eğitim öğretim sürecinin etkililiği, olumlu okul iklimi ve kültürü, okuldaki güven ortamı gibi birçok değişkenin ön plana çıktığı görülmektedir. MEB'de görev yapan öğretmenlerin çocuklarını özel okullara kayıt ettirmesinin nedenlerini, öğretmenlerin görüşlerinden hareketle belirlemeyi amaçlayan bu araştırma, nitel araştırma yöntemlerinden durum çalışması yöntemiyle desenlenmiştir. Araştırma, durum çalışması desenlerinden bütüncül tek durum deseninde yürütülmüştür. Araştırma 2020-2021 eğitim öğretim yılında Kocaeli ili İzmit ilçesinde bulunan devlet okullarında yürütülmüş olup, çalışma grubunun belirlenmesinde örneklem yöntemlerinden ölçüt örnekleme tercih edilmiştir. Katılımcıların 4'ü kadın 5'i erkektir. Verilerin analizinde, nitel veri analizi tekniklerinden içerik analizi tekniğgi kullanılmıştır. Araştırma sonuçları, öğretmenlerin çocukları için okul seçiminde özel okul tercih etme nedenlerinin, çocuklarının özel okullarda daha nitelikli bir eğitim aldıklarına inanmaları, özel okulların sağladığı fiziki şartlar, teknolojik imkânlar, öğretmenlerin özverili olması, okul çevresi, sportif faaliyetler, akademik başarı, öğretimde farklı yöntem ve tekniklerin kullanılması, yabancı dil eğitimi ve olumlu okul iklimi ile ilişkili olduğunu göstermektedir.

Anahtar Kelimeler: Okul tercihi, öğretmen, özel okul, veli

\section{The Reasons for Teachers Working at the State Schools to Enroll Their Children in Private Schools}

\begin{abstract}
Changes and developments in society shape families' perspective on education. Today, which is called the information age, the value of education has been understood and families have become interrogator, searcher and selective about their children's education. For this reason, families start to search for a qualified school while making their school choices. The searches on this subject have led to the evaluation of private schools as an alternative. Although state and private schools work under the Ministry of National Education, these two types of school differ from each other in terms of success, effectiveness and efficiency. These differences affect the preferences of parents when choosing a
\end{abstract}

${ }^{1}$ Okul Öncesi Öğretmeni, Milli Eğitim Bakanlığı, https://orcid.org/0000-0002-1371-2563, asametkurban@gmail.com 
school. On the subject of choosing private schools; many features such as the number of students in classes, the technological infrastructure of the school, the effectiveness of the education and training process, the positive school climate and culture, the environment of trust in the school have been effective. This study, which aims to determine the reasons for teachers working at the Ministry of National Education to enroll their children in private schools, within the framework of teachers' opinions, was designed with the case study method, one of the qualitative research methods. The research was conducted in a holistic single case pattern which is one of the case study designs. The study was conducted in the state schools in İzmit district of Kocaeli province in the 2020-2021 academic year and criteria sampling, one of the sampling methods, was preferred in determining the study group. Four of the participants are women and five are men. Descriptive analysis and content analysis style, which are among qualitative data analysis techniques, were used in the analysis of the data. Research results reveals that the reasons why teachers prefer private schools for their children are associated with believing that their children receive a more qualified education in private schools, physical conditions provided by private schools, technological opportunities, devotion of teachers, school environment, sports activities, academic success, use of different methods and techniques in teaching, foreign language education and a positive school climate.

Keywords: Parents, preference of school, private schools, teacher

\section{Giriş}

Okulun etkililiği, öğrencilerin akademik başarıyla özdeşleştirilse de okullar belirledikleri hedef ve amaçlarına ulaşabildiği ölçüde etkili olarak nitelendirilmiştir (Balc1, 1988). Etkili okul düşüncesinde, okulların farklılıklar yaratabileceği inancı egemendir. Etkili okullar, öğrencilerinin başarısı için uygun fiziksel ortamları, öğretim araç-gereçlerini ve okulun tüm kaynaklarını etkili biçimde kullanırlar. Öğrencilerin, bilişsel olduğu kadar duyuşsal açıdan da gelişmeleri sağlanır. Etkili okul olmak daha fazla kaynağa sahip olma anlamına gelmez, mevcut kaynaklarla daha iyi sonuçlara ulaşmayı ifade eder. Etkili okul, okuldaki eğitime temel olan şeylere sürekli vurgu yapılmasını öngörmektedir (Çubukçu \& Girmen, 2006: 16). Öğretme ve öğrenme etkinliklerinin yer aldığı eğitim-öğretim ortamı, öğrencilerin farklı öğrenme amaçları, ilgileri, gereksinimleri ve becerileri ile uygunluk içinde olmalıdır. Çünkü öğrencinin öğrenmesinde, sınıfa ve okula uyum sağlamasında fiziksel çevrenin önemli bir payı vardır. Sınıftaki öğrencilerin sayısı, duvar ve eşya renkleri, 1şık, 1sı, temizlik, gürültü düzeyleri ve görünüm, sınıftaki fiziksel ortamın öğeleri olarak sayılabilir (Başar, 2001: 25).

Günümüzde aileler okul seçimlerini yaparken nitelikli okul arayışına girmişlerdir. Bu konudaki arayışlar özel okulların alternatif olarak değerlendirmesine neden olmuştur. Eğitim ve öğretim faaliyetlerinin gerçekleştirilmesi amacıyla Milli Eğitim Bakanlığı'na bağlı olarak çalışan özel okullar ve devlet okulları bulunmaktadır. Devlet okulları, hükümet tarafından kurulan ve finanse edilen ve öğretmenleri ve öğrencileri denetlemek üzere hükümet tarafindan atanan müdürler tarafından yönetilen kurumlardır. Öte yandan özel okullar, özel sektör (bireyler ve sivil toplum kuruluşları) tarafından kurulan, finanse edilen ve yönetilen kurumlardır. Hem devlet okulları hem de özel okullar, öğrencileri yükseköğrenim ve toplumda faydalı bir yaşam için yetiştirmek amacıyla aynı müfredatı uygular. Belirlenen eğitim hedeflerine ulaşılması, büyük ölçüde okullarda öğretmenlerin öğretimsel iş yüklerinin etkili ve verimli bir şekilde yönetilmesine bağlıdır (Ayeni \& Prince, 2018). Devlet okulu, Milli Eğitim Bakanlığı'na bağlı olan, her türlü gideri devlet bütçesinden karşılanan, öğrenim çağındaki çocuklara ulusal eğitim amaçlarına göre eğitimin verildiği eğitim kurumlarıdır. Devlet okulundaki verilen eğitimin tüzüğünü, programını, içeriğini devlet kendisi hazırlar, burada verilen eğitimi denetler (Kırmızı, 2014: 8-9). Özel okullar, Milli Eğitim Bakanlığı'nın gözetim ve denetimi altında olmak şartıyla, 625 sayılı Özel Öğretim Kurumları Kanunu doğrultusunda yerli ve yabancı, gerçek ve tüzel kişilerce açılmış ve bir ücret karşıllı̆ında hizmet veren öğretim kurumlarıdır (Küçükçayır \& Cemaloğlu, 2017: 1). Özel okulların giderleri devlet bütçesinden karşılanmaz, bu okulların giderleri okul sahipleri tarafından karşılanır (Uygun, 2003: 107). 
Milli Eğitim Bakanlığı'na bağlı olarak çalışan özel öğretim okulları ve devlet okulları incelendiğinde okullar arasında başarı, etkililik ve verimlilik açısından farklılıklar bulunmaktadır. Özel okul ile devlet okulu arasındaki en büyük farklardan birisi yabancı dil öğretimidir. Özel okullarda yabancı dil öğretimi nitelikli bir şekilde verilirken, devlet okullarında okuyan öğrencilere yabancı dil öğretiminin nitelikli verilmediği düşünülmektedir (Nartgün, 2016: 162). Özel okullarda eğitim süreçleri teknolojiyle bütünleşmiş olup öğrenciler ve veliler öğrenme ortamlarında çeşitli araştırma, inceleme ve değerlendirme yapma imkânına sahiptirler. Devlet okullarındaki eğitim süreçlerindeki teknolojik gelişme ise özel okullara oranla daha azdır (Ünsal \& Çetin, 2018: 1543). Özel okullarda araç gereç, fen ve dil laboratuvarı gibi olanaklar yeterli iken devlet okullarında bu olanaklar yetersizdir (Kandemir, 2015: 38). Özel okuldaki sportif faaliyetler daha fazla ve çeşitlidir. Buralarda; futbol, basketbol, voleybol, tenis, yüzme vb. sportif faaliyetler yapılabilmektedir. Öğrenciler bu sportif faaliyetleri yaparken malzeme ve mekân sıkıntısı çekmezler. Devlet okullarında ise futbol, basketbol, voleybol ve masa tenisi gibi faaliyetlerin bazıları yapılabilmekte olup bunlar bile her zaman gerçekleştirilemez. Futbol oynamak isteyen öğrenciler futbol topu bulamaz veya her zaman futbol oynayacak alan yoktur. Öğrenciler basketbol oynamak istese çoğu zaman basket topu bulamaz; voleybol oynamak istese, voleybol topu veya filesi bulamaz. Ögrrenciler masa tenisi oynamak istediklerinde ise belki tenis masası bulabilir ama çoğu zaman raket veya pinpon topu yoktur. Masa tenisi oynamaya çok meraklı olan kimi öğrenciler, kendi raketlerini ve pinpon toplarını kendileri almak zorundadırlar (Çevik, 2005). Özel okullarda okul bahçesi öğrenci sayısına göre yeterlidir, devlet okullarında ise okul bahçesi öğrenci sayısına göre yetersizdir. Özel okullardaki öğrenci sayısı fazla değişmez, fakat devlet okullarındaki öğrenci sayısı sürekli artar. Öğrenci sayısı çok fazla artınca okul bahçesindeki eski okul binasının yanına yeni derslikler inşa edilir ve bu da bahçenin daha da yetersiz hale gelmesine yol açar (Bozyiğit, 2017). Özel okulda çalışan öğretmenler, devlet okulunda çalışan öğretmenlere oranla öğrencilerin sorunlarıyla daha çok ilgilenmektedirler. Burada özel okuldaki öğretmen başına düşen öğrenci sayısının devlet okulundakinden daha düşük olmasının da etkisi vardır. Devlet okulundaki öğrenci sayısı çok fazla olduğu için buradaki öğretmenler her öğrenciyle yeteri kadar ilgilenememektedir (Koç, 2019: 37-38). Özel okullardaki sınıflarda öğrenci sayısı azdır. Bu ise eğitimin kalitesini artırır. Çünkü az sayıdaki öğrencinin olduğu sınıflarda ders veren öğretmenler, öğrencilerle daha çok ilgilenebilmektedirler. Ayrıca az sayıdaki öğrenciden oluşan sinıfi kontrol etmek daha kolaydır (Kandemir, 2015: 36).

Devlet ve özel okul arasındaki farkl1liklar velilerin okul seçimi yaparken tercihlerini etkilemektedir. Devlet okulu seçiminde nitelikli okulların ve öğretmenlerin aranan özelliklerin başında geldiği görülmektedir. Bu tip okulların ise belirli çevrelerde toplandığı bazı bölgelerde ise öğretmen seçimlerinin okul seçimlerinden daha da önem kazandığ 1 düşünülmektedir. Mcnally'nin (2002) çalışmasında, ailelerin çocuklarını gönderdikleri okulları nasıl tercih ettiklerini araştırmış ve en önemli etkenlerin; okulun disiplini, öğretmenlerin iyi ve özverili oluşu, okulun güvenli bir ortama sahip olması ve sınıf mevcudunun az olması, olduğu saptamıştır. Velilerin okul seçerken yaşadıkları süreci devlet okullarında görev yapan öğretmenler de kendi çocukları için yaşamaktadırlar. Öğretmenlerin çocukları için nitelikli eğitim şartlarını devlet okullarının etkili ve yeterli düzeyde karşılamaması durumunda özel okulları tercih ettikleri görülmektedir. Devlet okullarında görev yapan öğretmenlerin çocukları için bağlı bulundukları kurumların yerine özel okulları tercih etmeleri bu öğretmenlerin devlet okullarının niteliğini ve etkililiğini sorguladığ 1 anlamına gelmektedir. Öğretmenler okul seçiminde; sınıf mevcudu, okulun teknolojik alt yapısı, eğitim öğretim sürecinin etkililiği, olumlu okul iklimi ve kültürü, okuldaki güven ortamı, sınavlarda başarı, bölgede bulunan okul seçenekleri, devlet okulları ve özel öğretim okulları arasında bulunan farklar, okul etkililiği gibi birçok özelliğin etkili olduğu söylenebilir. 
Devlet okullarında çalışan öğretmenlerin, devlet okullarındaki eksiklikleri ya da yanlış uygulamaları en iyi gözlemleyen ve deneyimleyen kişiler olduğu düşünüldüğünde, bu kesimde özel okul seçme eğilimi, özel okullar ve devlet okulları arasındaki farkı ortaya koymak açısından bir gösterge olarak görülebilir. Öğretmenlerin kendi çocukları için devlet okulları yerine özel okulları tercih etmelerine neden olan faktörler ile bu faktörlerin karar aşamasında öğretmenleri nasıl etkilediğine ilişkin tespitlerin ortaya konulması bu açıdan önem taşımaktadır. Türkiye'de velilerin okul tercihlerine ilişkin yapılan araştırmaların sınırlı sayıda olduğu söylenebilir. Ulusal alanyazında Turna ve Keskin (2010) bu konuda bir çalışma yapmışlardır. Çalışma incelendiğinde ailelerin sosyo-ekonomik düzeyleri, olumlu okul imaj1, okulun etkili yönetilmesi, öğretmen kalitesi, okulların geçmişte beklentileri karşılama düzeyi gibi faktörlerin etkisinde tercih yaptıklarını ortaya koymuşlardır. Literatürde öğretmenlerin tercihlerini belirlemeyi amaçlayan bir çalışma olmadığ görülmüştür. Bu doğrultuda bu çalışmada devlet okullarında görev yapan öğretmenlerin özel okullarda aradıkları özellikler, çocukları için okul seçimlerini etkileyen faktörler, çocuklarını özel okullara kayıt yaptırma nedenlerinin incelenmesi amaçlanmıştır. Bu amaç doğrultusunda; "Öğretmenlerin çocuklarının eğitimi için özel okulları tercih etme nedenleri nelerdir?" sorusuna yanıt aranmıştır.

\section{Yöntem}

\subsection{Araştırma Modeli}

MEB'de görev yapan öğretmenlerin çocuklarını özel okullara kayıt ettirmesinin nedenlerini öğretmenlerin görüşlerinden hareketle belirlemeyi amaçlayan bu çalışma, nitel araştırma yöntemlerinden durum çalışması yöntemiyle desenlenmiştir. Durum çalışması deseninde bir duruma ilişkin ortam, olaylar, bireyler, süreçler gibi etkenler bütüncül bir yaklaşımla, kendi doğal ortamında, yer ve zamanla sınırlı olarak araştırılmaktadır ve ilgili durumu nasıl etkiledikleri ve bu durumdan nasıl etkilendikleri üzerine odaklanılmaktadır (Yıldırım \& Şimşek, 2016). Durum çalışmaları gerçekte ortamda neler olduğuna bakma, sistematik bir biçimde verileri toplama, analiz etme ve sonuçları ortaya koyma yoludur. Ortaya çıkan ürün ise olayın niçin o şekilde olduğunun ve gelecek araştırmalar için daha detaylı olarak nelere odaklanmanın gerektiğinin keskin bir biçimde anlaşılmasıdır (Davey, 1991; akt. Aytaçl1, 2012). Araştırma, durum çalışması desenlerinden bütüncül tek durum deseninde yürütülmüştür. Bütüncül tek durum deseni, daha önce çalışılmamış, belirli bir konunun su yüzüne çıkması, daha sonra yapılacak araştırmalara temel oluşturması ve yol göstermesi açısından önem taşıyan nitel bir araştırma desenidir (Yıldırım \& Şimşek, 2011). Milli Eğitim Bakanlığında görev yapan öğretmenlerin çocukları için özel okul tercihlerini etkileyen nedenlere ilişkin daha önce yapılmış bir araştırmaya rastlanmamıştır. Bu nedenle araştırmanın konusu ile desenin örtüştüğü düşünülmektedir. Araştırmada ele alınan durum devlet okullarında görev yapan öğretmenlerin çocuklarını özel okullara kayıt yaptırması durumudur.

\section{2. Çalışma Grubu}

Araştırma 2020-2021 eğitim öğretim yılında Kocaeli ili İzmit ilçesinde bulunan devlet okullarında yürütülmüş olup, çalışma grubunun belirlenmesinde örneklem yöntemlerinden ölçüt örnekleme tercih edilmiştir. Ölçüt örnekleme, önceden belirlenmiş ölçütlerin karakteristik özelliklerini gösteren tüm durumların çalışılmasıdır. Ölçüt örneklemdeki asıl nokta seçilecek olan durumların bilgi verme açısından zengin olmasıdır (Patton, 2014). Ölçüt örnekleme yönteminde, evrenden belli niteliklere sahip kişiler, olaylar, nesneler ya da durumlar seçilir (Büyüköztürk vd., 2018). Araştırmada belirlenen ölçüt, öğretmenlerin devlet okullarında görev yapması ve çocuklarını özel okula kayıt ettirmesidir. Araştırma sorularına yanıt aramak amacıyla dokuz öğretmenin görüşlerine başvurulmuştur. Öğretmenlerle yapılan görüşmelerden elde edilen veriler 
tekrar etmeye başladığında görüşmeler sonlandırılmıştır. Bu nedenle iki katılımcının görüşleri çalışmaya eklenmemiştir. Nitel araştırmalarda görüşme yöntemi ile veri toplamada, derinlemesine bilgi elde etmek amacıyla az sayıdaki kişi ile görüşme yapma yolu benimsenmektedir (Yıldırım \& Şimşek, 2011). Bu nedenle çalışmada, 9 katılımcıdan alınan görüşler yeterli görülmüştür. Katılımcıların 4'ü kadın 5'i erkektir. Mesleki kıdemleri, 1 ile 23 yıl arasında değişmektedir. Öğretmenlerin, EÖ1 (erkek birinci öğretmen) ve KDÖ1 (kadın birinci öğretmen) şeklinde kodlar verilerek isimler gizli tutulmuştur. Tablo 1'de araştırmaya katılan ögretmenlerin betimleyici özellikleri sunulmuştur.

Tablo 1. Öğretmenlerin Betimleyici Özellikleri

\begin{tabular}{lllc}
\hline Katılımcılar & \multicolumn{1}{c}{ Cinsiyet } & \multicolumn{1}{c}{ Branş } & Kıdem \\
\hline EÖ1 & Erkek & Müzik & 17 \\
EÖ2 & Erkek & Sınıf & 15 \\
EÖ3 & Erkek & Sınıf & 23 \\
EÖ4 & Erkek & İngilizce & 8 \\
EÖ5 & Erkek & Edebiyat & 6 \\
KDÖ1 & Kadın & Okul Öncesi & 9 \\
KDÖ2 & Kadın & Okul Öncesi & 1 \\
KDÖ3 & Kadın & Sınıf & 5 \\
KDÖ4 & Kadın & Matematik & 7 \\
\hline
\end{tabular}

\subsection{Veri Toplama Araçları}

Veriler açık uçlu sorulardan oluşan yarı yapılandırılmış bir görüşme formu aracılığıyla yüz yüze görüşmeler yapılarak toplanmıştır.Yarı yapılandırılmış görüşmeler araştırmacıya görüşme sırasında açık uçlu ek soru sorabilme imkanı vermektedir (Büyüköztürk vd., 2012). Yarı yapılandırılmış görüşme soruları, görüşme öncesi hazırlanır fakat görüşme esnasında sorular yeniden düzenlenebilir. Bu sorular, tam yapılandırılmış görüşmeler kadar katı, yapılandırılmamış görüşmeler kadar da esnek değildir (Merriam, 2018).

Görüşme formunda öğretmenlere yöneltilen 2 adet soru yer almaktadır. Hazırlanan sorular, dil, anlam, açıklık ve konuya uygunluk bakımından değerlendirilmesi amacıyla 2 uzmanın görüşüne sunulmuştur. Uzmanlardan gelen öneriler doğrultusunda soru sayısı değişmemiş; ancak soruların daha anlaşılır olmasına yönelik bazı düzenlemeler yapılmıştır. Uzman görüşleri neticesinde muhtemel sondalar eklenmiştir. Böylece kapsam geçerliliği sağlanmaya çalışılmıştır. Soruların açık, net ve anlaşılır olduğunu tespit etmek amacıyla iki öğretmenle pilot görüşmeler yapılmıştır. Yapılan pilot görüşmelerden birincisi 30 dakika ikincisi 35 dakika sürmüştür. Pilot görüşmeler sonucunda soruların anlaşılırlığında herhangi bir sorun olmadığı görülmüştür. Bu doğrultuda soruların iç geçerliliği sağlanmaya çalışılmıştır.

\subsection{Veri Toplama Süreci}

Belirlenen öğretmenlerle tanışmak ve randevu almak amacıyla ön görüşmeler yapılmış; gönüllü olan öğretmenlerden, uygun gün ve saatte görüşmek üzere randevu alınmıştır. Görüşme öncesinde öğretmenlere araştırmanın amacı detaylı şekilde anlatılmıştır. Görüşmeler esnasında alternatif sorulara yer verilmiş, gerektiğinde sonda sorular sorulmuştur. Öğretmenlerin kendilerini rahat ifade edebilmeleri açısından görüşmenın sohbet havasında geçmesi sağlanmıştır. Görüşmelere başlanmadan önce öğretmenlerden gerekli izinleri alınmıştır. Görüşmeler yazılı ve sesli olarak kaydedilmiştir. Görüşmeler 30 dakika ile 45 dakika arasında değişiklik göstermiştir. 
Devlet Okullarında Görev Yapan Öğretmenlerin Çocuklarını Özel Okullara Kayıt Yaptırmasının Nedenleri

\subsection{Verilerin Analizi}

Veri toplama sürecinde araştırmaya katılmaya gönüllü olan öğretmenlerle bire bir olarak veri toplama ile ilgili görüşülmüş ve görüşme sorularını sözlü olarak yanıtlamaları istenmiştir. Verilerin analizinde, nitel veri analizi tekniklerinden içerik analizi tekniği kullanılmıştır. Elde edilen verilerin ayrıntılı bir şekilde analiz edilmesi, birbirine benzeyen verilerin belirli temalar çerçevesinde bir araya getirilmesi işlemine içerik analizi denilmektedir. Yöntem, önceden belirgin olmayan temaların ve boyutların ortaya çıkarılmasına olanak tanımaktadır (Yıldırım \& Şimşek, 2008).

Nitel araştırmalarda veri analizi süreci ilk görüşme dökümlerini okumakla başlar (Merriam, 2018). Bu doğrultuda, görüşme dökümleri oluşturulduktan sonra birkaç kez okuma yapılarak anlamlı örüntülere ulaşmak amacıyla kodlar çıkarılmıştır. Araştırmacı ve alanda uzman bir öğretim üyesi, öğretmenlerin görüşlerini ayrı ayrı kodlamıştır. Tespit edilen kodlar incelenerek Miles ve Huberman'ın (2016) önerdiği uyuşum yüzdesi formülü (Güvenirlik=Görüş Birliği/[Görüş Birliği+Görüş Ayrılığı] x100) kullanılmıştır. Uyuşum yüzdesi formülü sonucunda kodlayıcılar arasında görüş uyum oranı .82 olarak bulunmuştur. Elde edilen kodlardan benzer olanlar aynı alt temada toplanmıştır. Alt temalar incelenerek, ilişkili olan temalar altında toplanmıştır. Bir sonraki aşamada elde edilen bulgular tanımlanmış ve yorumlanmıştır. Öğretmenlerin görüşleri yorumlanmadan doğrudan alıntı yoluyla verilmiştir.

\subsection{Geçerlik ve Güvenirlik}

Nitel araştırmada geçerlik bilimsel bulguların doğruluğu, güvenirlik ise bilimsel bulguların tekrarlanabilirliği ile ilgilidir (Yıldırım \& Şimşek, 2018). Bu doğrultuda geçerlik ve güvenirliğin sağlanması için çeşitli çalışmalar yapılmıştır. Bu çalışmalarda; iki öğretmenle ayrı ayrı 30'ar dakika süren pilot görüşmeler yapılarak soruların anlaşılırlığında herhangi bir sorun olmadığı test edilmiştir. Yarı yapılandırılmış form oluşturulurken ilgili alan yazını incelenmiş ve uzman görüşleri alınmıştır. Böylece sorularda iç geçerlilik sağlanmaya çalışılmıştır. Öğretmenlere isimlerinin ve okullarının gizli kalacağı güvencesi verilmiştir. Elde edilen bulgular öğretmenlere sunularak teyit alınmıştır. Öğretmenlerin görüşmelerde rahat olmalarını sağlamak adına sorulara hazır oldukları zaman geçilmiştir. Nitel araştırma alanında deneyimli bir öğretim üyesi bağımsız kodlamalar yapmış ve kodlamalar karşılaştırılmıştır. Araştırmacı ve alanında uzman öğretim üyesinin yaptığ (2016) önerdiği uyuşum yüzdesi formülü kullanılmıştır.

\subsection{Etik Kurul İzin}

Yapılan bu çalışmada "Yükseköğretim Kurumları Bilimsel Araştırma ve Yayın Etiği Yönergesi" kapsamında uyulması belirtilen tüm kurallara uyulmuştur. Bu çalışma için etik kurul izni Düzce Üniversitesi Bilimsel Araştırma ve Yayın Etik Kurulu'nun 24.06.2021 tarihli ve 2021/160 numaralı kararı ile alınmıştır.

\section{Bulgular}

\section{1. Öğretmenlerin Çocuklarını Özel Okullara Göndermeye İlişkin Görüşleri}

Araştırmanın sorusu "Çocuklarının eğitimi için özel okulları tercih etme nedenleri nelerdir?" şeklindedir. Her bir alt temaya ilişkin kodlar öğretmenlerden bazılarının ifadeleriyle direkt aktarılmıştır. Katılımcılara yöneltilen araştırma soruları bağlamında elde edilen veriler; öğretmenlerin çocuklarını özel okula gönderme nedenleri temasında toplanmıştır. Öğretmenlerin 
çocuklarını özel okula gönderme nedenleri teması, örgütsel özellikler, eğitim-öğretim ve çevresel özellikler olmak üzere üç alt tema altında gruplandırılmıştır. Araştırma katılımcılarının çocuklarını özel okula gönderme nedenleri hakkındaki görüşleri doğrultusunda ortaya çıkan ana tema ve alt temaların öğretmen görüşlerine göre dağılımları Tablo 2'de verilmektedir:

Tablo 2. Öğretmenlerin Çocuklarını Özel Okula Gönderme Nedenleri

\begin{tabular}{|c|c|c|c|}
\hline Tema & $\begin{array}{c}\text { Alt } \\
\text { Temalar }\end{array}$ & Kodlar & Katılımcı \\
\hline \multirow{22}{*}{ 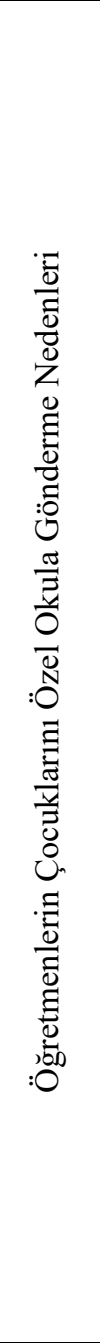 } & \multirow{11}{*}{ 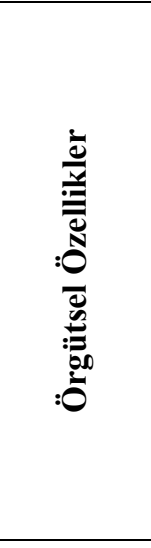 } & Fiziksel ve donanımsal yeterlilik & $\begin{array}{l}\text { (EÖ1), } \\
\text { (EDÖ2), } \\
\text { (KDÖ1) (KDÖ2), (EÖ5), }\end{array}$ \\
\hline & & Gelissmiş teknolojik alt yap1 & (KDÖ1), (EÖ2), (KDÖ3) \\
\hline & & Kalabalık olmayan sinif mevcutları & $\begin{array}{l}\text { (EÖ1), (EÖ2), (EÖ3), (EÖ4), } \\
\text { (KDÖ1), (KDÖ2), (KDÖ3), (KDÖ4) }\end{array}$ \\
\hline & & Sportif ve sanatsal faaliyetler & (EÖ4), (KDÖ1), (EÖ5) \\
\hline & & Yabancı okullarla ortaklıklar & (EÖ2) \\
\hline & & Yabancı öğretmenler & (KDÖ1), (KDÖ3) \\
\hline & & Ulaşım ve servis imkânları & (EÖ1), (KDÖ2) \\
\hline & & Olumlu okul iklimi & (EÖ2), (EÖ3), (KDÖ2) \\
\hline & & Eğitim süresinin tam gün olması & (EÖ2), (EÖ3), (KDÖ1), (KDÖ2) \\
\hline & & Beslenme imkanları & (KDÖ2) \\
\hline & & Okulların maddi imkanları & (EÖ2), (KDÖ1), (EÖ5), (KDÖ4) \\
\hline & \multirow{8}{*}{ 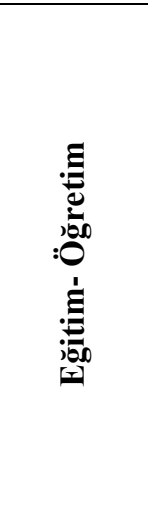 } & Rehberlik hizmeti & (EÖ2) \\
\hline & & $\begin{array}{l}\text { Farklı yöntem ve tekniklerin } \\
\text { kullanılması }\end{array}$ & (EÖ2), (EÖ3), (EÖ4), (KDÖ2) \\
\hline & & Yabancı dil eğitimi & (EÖ2), (EÖ4), (KDÖ3) \\
\hline & & Bireyselleștirilmiş müfredat & (EÖ2), (EÖ3), (KDÖ1) \\
\hline & & Akademik başarı & $\begin{array}{l}\text { (EÖ1), (EÖ2), } \\
\text { (KDÖ1), (KDÖ2) }\end{array}$ \\
\hline & & $\begin{array}{l}\text { Yaparak yaşayarak öğrenme imkânları } \\
\text { İyi/özverili öğretmen kadrosu }\end{array}$ & $\begin{array}{l}\text { (EÖ2), (KDÖ1), (KDÖ3), (KDÖ4) } \\
\text { (EÖ1), (EÖ2), (EÖ3), (EÖ4), } \\
\text { (KDÖ1), (KDÖ2), (EÖ5) }\end{array}$ \\
\hline & & Nitelikli öğretmenler & (EÖ3), (EÖ4), (KDÖ1), (KDÖ2) \\
\hline & & Ders seçme imkânı & (EÖ3) \\
\hline & \multirow{3}{*}{ 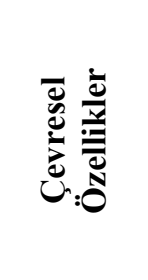 } & Eğitimli/bilinçli veli & $\begin{array}{llll}\text { (EÖ2), } & \text { (EÖ3), } & \text { (EÖ4), } & \text { (EÖ5), } \\
\text { (KDÖ1), (KDÖ4) }\end{array}$ \\
\hline & & Olumlu sosyo kültürel çevre & $\begin{array}{ll}(\mathrm{EÖ1}), & (\text { EÖ2), } \\
\text { (EÖ4),(KDÖ1), } & \text { (KDÖ3), } \\
\text { (KDÖ3) } & \text { (EÖ5), }\end{array}$ \\
\hline & & Güvenli okul çevresi & $\begin{array}{l}\text { (EÖ1), (EÖ4), (KDÖ1), (KDÖ2), } \\
\text { (EÖ5) }\end{array}$ \\
\hline
\end{tabular}

\subsection{1. Öğretmenlerin Çocuklarını Özel Okula Göndermesinde Örgütsel Özelliklere İlişkin Görüşler}

Öğretmenlerin fiziki şartlanı yeterli olan, sınıf ortamları kalabalık olmayan ve olumlu okul iklimini tesis edebilmiş okulları tercih ettikleri görülmektedir. Bir öğretmen, yabancı okullarla ortaklıkların hem çevre hem yabancı dil öğrenme açısından önemli olduğuna vurgu yapmıştır. Aşağıda öğretmenlerin görüşlerinden bazı doğrudan alıntılar yer almaktadır:

"Okul imkânlarının daha iyi olması, farklı yöntem ve teknikleri uygulayacak fiziki imkânlara sahip olunmast..." (KDÖ2)

“Sınıfların farkl yöntem ve teknikleri uygulayamayacak bir sınıf mevcudunda olması...” (KDÖ2) 
Devlet Okullarında Görev Yapan Öğretmenlerin Çocuklarını Özel Okullara Kayıt Yaptırmasının Nedenleri

“Okulda beklediğim en önemli özellik okulun bir kültürü olması.” (EÖ1)

"Özel okullardaki eğitsel materyal, teknolojik donanımların çocuklara farklı bakış açıları kazandırdıklarını düşünüyorum.” (KDÖ1)

“Bir okulun spor salonunun olması, bahçesinin oyun oynamaya müsait olması...” (EÖ4)

"Devlet okullarında yemek ve beslenme imkânlarının yetersiz olması çocukların gelişimini olumsuz etkilemektedir." (KDÖ2)

\subsection{2. Öğretmenlerin Çocuklarını Özel Okula Göndermesinde Eğitim Öğretime İlişkin Görüşler}

Öğretmenler öğrenme sürecinde farklı yöntem ve tekniklerin kullanılmasının, yaparak ve yaşayarak öğrenmenin çocukların öğrenme becerilerini artıracağını ifade etmişlerdir. Okulların iyi ve özverili öğretmen kadrosunna sahip olmasının tercihlerini etkileyen önemli faktörlerden olduğu görülmüştür. Aşağıda öğretmenlerin görüşlerinden bazı doğrudan alıntılar yer almaktadır.

"Eğitim anlayışı genel anlamda çocukların tüm duygularına hitap edecek farkl yöntem ve teknikleri kullanilabilecek..." (KDÖ2)

“Yabancı dil eğitimini çok önemsiyorum.” (EÖ4)

“Çocuğun eğitim alırken sadece kağıt ve kalemle eğitim almasını doğru bulmuyorum.” (KDÖ3)

“Zorunlu dersler olması gerektiği gibi seçmeli derslerinde olması gereklidir.” (EÖ3)

“Yaparak yaşayarak ögrenmek bilgilerin kalıcılı̆̆ını sağlıyor.” (KDÖ4)

“Özel okullarda çocuklar değerlendirilirken birden fazla gözetmen bunu yapmakta.” (EÖ2)

\subsection{3. Öğretmenlerin Çocuklarını Özel Okula Göndermesinde Çevresel Özelliklere İlişkin Görüsşler}

Okulların seçiminde eğitimli ve bilinçli veliler, güvenli okul çevresi ve okulun güvenli bir çevrede bulunuyor olması öğretmenlerin tercihlerini etkilemiştir. Öğretmenler özellikle okulun güvenli bir çevrede olmasının çocuklarının güvenliği ve çevreden olumlu etkilenmeleri açısından önemli olduğunu vurgulamışlardır. Aşağıda öğretmenlerin görüşlerinden bazı doğrudan alıntılar yer almaktadir.

"Devlet okullarında potansiyelleri, gelişim özellikleri farklı olan çok farklı kültürlerden oluşmuş kozmopolit bir yapı bulunuyor..." (EÖ2)

“Özel okullara öğrencisini kaydettiren velinin daha bilinçli olacă̆ına inanıyorum...” (KDÖ4)

“...çocuğumun akran grubundan alacağı olumlu davranışlarla gelişmesini isterim.” (EÖ3)

“Çocuğumun arkadaşları ile karşılıklı bilgi alışverişi içerisinde olmasını isterim...” (EÖ5)

"Benim için evrensel değerleri göz önünde bulunduran bu değerleri çocuğuma katabilecek bir okul aradım." (EÖ3) 
“... çocuğumun okulunda ĕgitimi bilen anlayan eğitime gerekli önemi veren velilerin olmasını isterim." (EÖ5)

\section{Tartışma ve Sonuç}

Araştırma sonuçlarına göre; devlet okullarında çalışan öğretmenler, çocukları için özel okul tercihinde örgütsel özellikler temasına yönelik, fiziki şartlarının yeterli olması, sınıf mevcutlarının az olması, eğitimin tam gün olması, maddi imkanlar, eğitim süresinin tam gün olması, beslenme imkanları ve olumlu okul iklimine yönelik vurguda bulunmuşlardır.

Özkara'nın (2002) araştırmasında; okul seçiminde tam gün eğitim imkânı verilmesi en önemli beklentilerden olduğu belirtilmiştir. Pulat (2019) tarafından yapılan çalışmaya göre, velilerin okul tercih etme sebeplerini etkileyen faktörler yüksekten düşüğe doğru şöyle sıralanmaktadır; okulun fiziki şartları, ekonomik kaynaklar, iletişim süreçleri, sanatsal, sportif, sosyal, kültürel ve eğitim öğretim faaliyetleridir. Sınıf mevcutlarının öğretmenlerin okul seçiminde önemli olduğu görülmüştür. Garbarino (1980) tarafindan yapılan çalışmaya göre, 13-17 kişilik sınıflardaki öğrencilerin Stanford Başarı Testi'nde 22-25 kişilik sınıflardaki öğrencilerden daha başarılı oldukları belirlenmiştir. Özellikle de erken yaşlarda küçük sınıflarda olan çocukların büyük sınıflardakilere kıyasla tüm derslerde daha başarılı oldukları görülmüştür. Aydoğan (2012) tarafından yapılan çalışmaya göre; sınıf büyüklükleri, sınıftaki öğrenci sayısı, sıraların yerleştiriliş şekli, okuldaki mobilya ve döşemelerin nitelikleri, okulun ve sınıfın sahip olduğu teknolojik aletler, okul binasının büyüklüğü, laboratuvar ve kütüphane gibi öğrenme ortamlarının bina içindeki yerleri, öğretmenler odasının yeri ve niteliği gibi birçok fiziksel şartın eğitim-öğretim faaliyetlerini şekillendirdiği, öğrenci ve çalışanların davranışlarını önemli ölçüde etkilediği görülmektedir. Akhan'ın (2009) araştırmasına göre; okula ilişkin fiziksel olanakların çeşitli ve zengin olması, ulaşım (servis) olanaklarının yeterli düzeyde olması, eğitimin tam gün devam etmesi, sınıflarda az sayıda öğrenci bulunması ailelerin özel okulları tercih etme nedenleri arasında gösterilmiştir. Veliler, okulların sunduğu en iyi hizmetten yararlanmak isterler. Bu sebeple veliler çocuklarını, eğitim kalitesi yüksek, çevrede iyi bir imaja sahip ve iyi yönetilen okullara kayıt ettirmek istemektedirler. Demir' in (2000) araştırmasına göre; öğrencilerin gelişim sürecine yarar sağlayabilecek, ailelere yol haritası sunabilecek bir rehberlik servisinin olması, dersliklerde az sayıda ögrenci bulunması, ögretmenlerin demokratik bir ortam yaratması, fen ve bilgisayar laboratuvarı, diğer araç-gereçler açısından donanımlı bir okul olması ve teknolojinin yakından izlenmesi özel okulu tercih eden ailelerin beklentileridir. Özkaya'nın (2021) araştırmasına göre devlet okullarında görev yapan yönetcilerinin olumsuz tutum ve davranışları okul etkililiği üzerinde engeller oluşturmaktadır. Akdoğan'ın (2014) araştırmasına göre, veliler okulda kaliteli bir eğitim verilmesini, okulun temiz olmasını, veli ile sürekli iletişim halinde bulunulmasını, görüşleri alınarak onlara değer verilmesini, güler yüzlü karşılanmak istediklerini, öğrencilerin iyi takip edilerek etkili yönlendirmeler yapılmasını, yöneticilerin kendisini ve kadrosunu sürekli geliştirmesini, aile eğitimleri verilmesini beklemektedirler.

Araştırma sonuçlarına göre; devlet okullarında çalışan öğretmenler çocukları için özel okul tercihinde eğitim-öğretim temasına yönelik, farklı yöntem ve tekniklerin kullanılması, öğretmen kadrosunun kaliteli ve seçilmiş öğretmenlerden oluşması, akademik başarı, yabancı dil eğitimi, bireyselleştirilmiş müfredat, yaparak yaşayarak öğrenme imkanı ve ders seçme imkanına vurguda bulunmuşlardır.

Ergin'nin (1993) araştırmasına göre velilerin okul tercih sebepleri; öğretmen kadrosunun kalitesi, yabanc1 dil eğitimindeki başarısı, ikinci bir yabancı dil eğitimi vermesi, okulun yönetimi, laboratuvar ve bilgisayar olanaklarının olması, sosyal ve sportif faaliyetlerin çeşitliliği şeklindedir. Hesapçığlu ve Nohutçu'nun (1999) araştırmasına göre, okulun doğrudan tanıtımının (öğretimin kalitesi, öğretim kadrosu, sosyal etkinlikler, yabancı dil eğitimi, mezunların başarıları) 
önemli olduğu söylenmiştir. Dikbaş'ın (2018) araştırmasına göre, öğrencilere nitelikli bir eğitim hizmeti sunulması, yabancı dil eğitimine önem verilmesi ailelerin özel okul seçimlerinde belirleyicidir. Berberoğlu ve Kalender'in (2005) araştırmasına göre, toplumda özel okullara göre devlet okullarının daha düşük performanslı olduğu kanaati yaygındır. Özel liselerde okuyan öğrenciler, devlet liselerinde okuyan öğrencilere göre üniversite giriş sınavlarında daha başarılı olmaktadırlar. $\mathrm{Bu}$ durumun oluşmasında özel liselerde okuyan öğrencilerin iyi bir eğitim almasının yanında, bu öğrencilerin notlarının yüksek gösterilmesinin de payı vardır. Hesapçığlu ve Nohutçu'nun (1999) araştırmasına göre, velilerin özel okullarda aradıkları özellikler; eğitimöğretim kadrosunun nitelikleri, yabancı dil öğrenme imkânları ve öğretim sürecidir. Devlet okullarının nitelik açısından yetersiz düzeyde olması, giderek artan öğrenci kapasitesini karşılayamaması ve ailelerin çocuklarına daha iyi bir eğitim sağlama isteği, özel okulların tercih edilmesini destekler niteliktedir (Kulaksızoğlu, Dilmaç \& Çakar, 1999).

Araştırma sonuçlarına göre; devlet okullarında çalışan öğretmenler, çocukları için özel okul tercihinde çevresel özellikler temasına yönelik, eğitimli/bilinçli veli, sosyo kültürel özellikler, devlet okullarının kozmopolit yapısı, çevre ve güvenli okul çevresine vurguda bulunmuşlardır. Elde edilen sonuçlarına göre, aileler çocuklarının güvenli bir ortamda eğitim alması yönünde görüş belirtmişlerdir. Özellikle aileler çocuklarının okulun çevresinden etkilenmesinden ve informal öğrenmeler sonucu olumsuz öğrenmeler yaşamalarından endişe duyduğu görülmektedir. Smedley'in (1995) araştırmasına göre velilerin özel okulları tercih etme nedenleri; emniyet, güvenlik ve okulun yakınlığı olarak ortaya çıkmıştır. Okulunun sosyo ekonomik çevresi ve kozmopolit bir yapıdan oluşması öğretmenlerin tercihlerini etkilediği görülmüştür. Okulun sosyo ekonomik çevresi, okul etkililiği üzerinde belirleyicidir (Kazak, 2021).

Araştırmadan elde edilen sonuçlar bağlamında aşağıdaki önerilerde bulunulabilir:

1. Devlet okullarında çalışan öğretmenlerin, kişisel ve mesleki gelişimlerine olanak sağlayan daha nitelikli hizmet içi eğitimlere yer verilebilir.

2. Öğretmenlerin yer değişikliği taleplerinin azaltılmasına yönelik teşvik edici tedbirler alınabilir.

3. Devlet okullarında sınıf mevcutlarının minimum düzeyde tutularak öğretmen ve öğrenci performansının arttırılmasını sağlayıcı gerekli çalışmalar yapılabilir.

4. Devlet okullarında öğrencilerin bedensel ve zihinsel gelişimlerine uygun beslenme ihtiyaçları dikkate alınarak okul yemekhanelerinin hizmet vermesi sağlanabilir.

5. Öğrencilerin okula ulaşımında yaşadıkları zorluklar göz önünde bulundurularak gerekli tedbirlerin alınması sağlanabilir.

6. Devlet okullarında öğrencilere yaparak yaşayarak öğrenme imkanları sağlayan materyaller, atölyeler ve laboratuvar kurulmasi; sosyal, sportif ve kültürel anlamda gelişimlerine katkı sağlayacak fiziksel olanakların oluşturulması sağlanabilir.

7. İleride yapılacak çalışmalarda öğretmen eşleri ve çocukları ile görüşmeler yapılabilir. Görüşmelere ek olarak okul ortamlarında gözlemler yapılabilir.

\section{Kaynaklar}

Akdoğan, H. (2014). Velilerin öğrenci başarısı için okul yönetimi ve öğretmenlerden beklentileri (Yayınlanmamış yüksek lisans tezi). Fatih Üniversitesi Sosyal Bilimler Enstitüsü, İstanbul.

Akhan, A. (2009). Velilerin özel ilköğretim okullarından beklentileri ve beklentilerinin karşılanma düzeyleri (İstanbul Avrupa Yakası örneği) (Yayınlanmamış yüksek lisans tezi). Yeditepe Üniversitesi Sosyal Bilimler Enstitüsü, İstanbul. 
Arslantaş, H. İ., \& Özkan, M. (2014). Öğretmen ve yönetici gözüyle etkili okulda yönetici özelliklerinin belirlenmesi. The Journal of Academic Social Science Studies, 8(26), 181193.

Ayeni, Adeolu., \& Prince, Arinze. (2018). Teachers' instructional workload management and students' academic performance in public and private secondary schools in akoko northeast local government, ondo state, Nigeria. American International Journal of Education and Linguistics Research, 1(1), 9-23.

Aydoğan, İ. (2012). Okul binalarının özellikleri ve öğrenciler üzerine etkileri. Milli Eğitim Dergisi, 42(193), 29-43.

Balc1, A. (1988). Etkili okul. Eğitim ve Bilim Dergisi, 12(70), 25-26.

Berberoğlu G., \& Kalender İ. (2005). Öğrenci başarısının yıllara, okul türlerine, bölgelere göre incelenmesi: ÖSS ve PISA analizi. ODTÜ Ë̆itim Bilimleri ve Uygulama Dergisi, 4(7), 27-28.

Bozyiğit, S. (2017). Özel okulların eğitim hizmetlerine ilişkin veli beklentisi ve algısı: Nitel bir araştırma. 2nd International Congress on Political, Economic and Social Studies (ICPESS), Niğde.

Büyüköztürk, Ş., Kılıç Çakmak, E., Akgün, Ö. E., Karadeniz, Ş., \& Demirel, F. (2018). Bilimsel araştırma yöntemleri. Ankara: Pegem Akademi.

Çevik, S. (2005). Özel okul ve kamu okullarının spora ayırdıkları finansman ve sportif başarılarının karşılaş̧tırılması (İstanbul ili ortaögretim okulları örneği) (Yüksek Lisans Tezi). Marmara Üniversitesi Sağlık Bilimleri Enstitüsü, İstanbul.

Çubukçu, Z., \& Girmen, P. (2006). Ortaöğretim kurumlarının etkili okul özelliklerine sahip olma düzeyleri. Manas Üniversitesi Sosyal Bilimler Dergisi, 8(16), 121-136.

Davey, L. (2009). The application of case study evaluations. Elementary Education Online, 8(2), $1-3$.

Demir, Z. (2000). Öğrenci velilerinin beklentileri açısından özel ve resmi ilköğretim okullarının karşılaştırılması (Niğde il örneği) (Yayınlanmamış Yüksek Lisans Tezi). Niğde Üniversitesi, Sosyal Bilimler Enstitüsü, Niğde.

Dikbaş, İ. (2008). Veli beklentileri ve karşılanma düzeyleri: özel vakıf okulları örneği (Yayınlanmamış Yüksek Lisans Tezi). Yeditepe Üniversitesi Sosyal Bilimler Enstitüsü, İstanbul.

Erdoğan, İ. (2002). Yeni bir binyıla doğru türk eğitim sistemi sorunlar ve çözümler. İstanbul: Sistem Yayıncilik.

Ergin, D. Y. (1993). Özel bir kolejde yapılan imaj araşstırması. İstanbul: Kültür Koleji Yayınları.

Hesapçığlu, M., \& Nohutçu, A. (1999). Velilerin özel okul tercihlerini etkileyen faktörler ve özel okulların reklam stratejileri. M. Ü. Atatürk Eğitim Fakültesi Eğitim Bilimleri Dergisi, $11,183-202$.

Kandemir, Y. (2015). Devlet okulu öğretmenlerinin özel okullara ilişkin tutumlarının incelenmesi (Yayınlanmamış Yüksek Lisans Tezi). Yeditepe Üniversitesi Eğitim Bilimleri Enstitüsü, İstanbul.

Kazak, E. (2021). Farklı sosyo ekonomik çevrelerde bulunan okulların etkililiğine ilişkin öğretmenlerin görüssleri. Bolu Abant İzzet Baysal Üniversitesi Eğitim Fakültesi Dergisi, 21(1), 139-161. 
Devlet Okullarında Görev Yapan Öğretmenlerin Çocuklarını Özel Okullara Kayıt Yaptırmasının Nedenleri

Kırmızı, R. (2014). Özel liselerin türk eğitim sistemindeki yerinin iktisadi ve mali açıdan değerlendirilmesi (Yüksek Lisans Tezi). Adnan Menderes Üniversitesi Sosyal Bilimler Enstitüsü, Aydın.

Koç, A. F. (2019). Okul kültürünün özel okullarda ve devlet okullarında çalışan sosyal bilgiler ögretmenlerinin uygulamalarına etkisi (Yayınlanmamış Yüksek Lisans Tezi). Erciyes Üniversitesi Eğitim Bilimleri Enstitüsü, Kayseri.

Kulaksızoğlu, A., Çakar, M., \& Dilmaç, M. (1999). Türkiye'de özel okullar hakkındaki tutumla ilgili bir araştırma. Marmara Üniversitesi Atatürk Eğitim Fakültesi Dergisi, 11, 233-246.

Küçükçayır, A. G., \& Cemaloğlu, N.(2017). Türkiye'de geçmişten günümüze özel okullar ve uygulanan politikalar üzerine bir araştırma, 12.Uluslararası Eğitim Yönetimi Kongresi, Ankara.

Merriam, S. B. (2018). Nitel araştırma desen ve uygulama için bir rehber (Çev. S. Turan). Ankara: Nobel Yayınları

Mcnally, C. P. (2002). Factors influencing family choice of elementary magnet schools for their children. Dissertation Abstracts International, 63(5), 1719-1864.

Miles, M. B., \& Huberman, A. M. (2016). Nitel veri analizi (Çev. S. A. Altun \& A. Ersoy). Ankara: Pegem Akademi.

Nartgün, Ş., \& Kaya, A. (2016). Özel okul velilerinin beklentileri doğrultusunda okul imaj1 oluşturma. Ë̆itim ve Öğretim Araştırmaları Dergisi, 5(2), 153-167.

Özkaya, F. (2021). Okul etkililiğinin önündeki engellere ilişkin okul müdürlerinin görüşleri. AJELI - Anatolian Journal of Educational Leadership and Instruction, 9(1), 119-144.

Patton, M. Q. (2014). Nitel araştırma ve değerlendirme yöntemleri (Çev. Ed. M. Bütün \& S. Beşir Demir). Ankara: Pegem Yayınları.

Pulat, A. (2019). Illkokul velilerinin özel okul tercihlerine etki eden faktörlerin incelenmesi (Yüksek Lisans Tezi). Sabahattin Zaim Üniversitesi Sosyal Bilimler Enstitüsü, İstanbul.

Subaşı, B., \& Dinler, A. (2003). Dünyada ve Türkiye'de özel okullar. İstanbul: İTO Yayınları.

Uygun, S. (2003). Türkiye'de dünden bugüne özel okullara bir bakış. Ankara Üniversitesi Eğitim Bilimleri Fakültesi Dergisi, 36, 107-120.

Ünsal, S., \& Çetin, A. (2019). Özel okul ve devlet okulunda görev yapmış sınıf öğretmenlerinin programlarını uygulamada karşılaştıkları farklılıklar. Kastamonu Eğitim Dergisi, 27, 1541-1551.

Yıldırım, A., \& Şimşek, H. (2016). Sosyal bilimlerde nitel araştırma yöntemleri. Ankara: Seçkin.

Yıldırım, N. (2007). Milli eğitim bakanlı̆̆ına bă̆lı okullarda kurum imajı ve halkla ilişkiler çalışmaları (Malatya örneği) (Yüksek Lisans Tezi). İnönü Üniversitesi Sosyal Bilimler Enstitüsü, Malatya.

\section{EXTENDED ABSTRACT}

\section{Introduction}

Changes and developments in society shape families' perspective on education. Today, which is called the information age, the value of education has been understood and families have become interrogator, searcher and selective about their children's education. The contribution of education 
to physical, social, physical and mental skills has been a remarkable element. For this reason, families start to search for a qualified school while making their school choices. The searches on this subject have led to the evaluation of private schools as an alternative. Although state and private schools work under the Ministry of National Education, these two types of school differ from each other in terms of success, effectiveness and efficiency. These differences affect the preferences of parents when choosing a school. On the subject of choosing a school; many features such as the class size, the technological infrastructure of the school, the effectiveness of the education and training process, the positive school climate and culture, the environment of trust in the school have been effective. This study, which aims to determine the reasons for teachers working at the Ministry of National Education to enroll their children in private schools, within the framework of teachers' opinions, was designed with the case study method, one of the qualitative research methods. The research was conducted in a holistic single case pattern which is one of the case study designs. The study was conducted in the state schools in İzmit district of Kocaeli province in the 2020-2021 academic year and criteria sampling, one of the sampling methods, was preferred in determining the study group. Four of the participants are women and five are men. Content analysis style, which is among qualitative data analysis techniques, were used in the analysis of the data. Research results reveals that the reasons why teachers prefer private schools for their children are associated with believing that their children receive a more qualified education in private schools, physical conditions provided by private schools, technological opportunities, devotion of teachers, school environment, sports activities, academic success, use of different methods and techniques in teaching, foreign language education and a positive school climate.

\section{Purpose}

In this study, it was aimed to examine the reasons why teachers working at the Ministry of National Education choose a private schools for their children. For this purpose, answers to the questions of "What are the reasons for teachers to choose private schools for their children's education?" have been sought.

\section{Method}

This study, which aims to determine the reasons for teachers working at the Ministry of National Education to enroll their children in private schools, within the framework of teachers' opinions, was designed with the case study method, one of the qualitative research methods.

This study, which aims to determine the reasons for teachers working at the Ministry of National Education to enroll their children in private schools, within the framework of teachers' opinions, was designed with the case study method, one of the qualitative research methods. The research was conducted in a holistic single case pattern which is one of the case study designs. There has been no previous study on the reasons affecting private school preferences for the children of the teachers working at the Ministry of National Education. For this reason, it is thought that the subject of the research and the design are compatible with each other.

The study was conducted in the state schools in İzmit district of Kocaeli province in the 20202021 academic year and criteria sampling, one of the sampling methods, was preferred in determining the study group. The criteria determined in the study is that teachers work at state schools and enroll their children in a private school. In order to find answers to the research questions, nine teachers' opinions were taken. Four of the participants are women and five are men. Their professional seniority ranges from 1 to 23 years. 
The data were collected through an interview form consisting of open-ended questions by making a face to face interviews. There are two questions directed to teachers in the interview form. The questions were submitted to the opinion of two experts in order to evaluate them in terms of language, meaning, clarity and relevance to the subject. With the suggestions of the experts, the number of questions has not changed, however, some regulations have been made to make the questions more understandable. Possible probes were added as a result of expert opinions. By this way, the scope validity was tried to be ensured. Preliminary interviews were made to meet the determined teachers and make an appointment and appointments were made with the volunteer teachers to meet at the appropriate day and time. Before the interviews, the purpose of the research was explained to the teachers in detail. Alternative questions were included during the interviews and when it was necessary, probe questions were asked. In order for the teachers to express themselves comfortably, the meeting was held in a conversation atmosphere. Before starting the interviews, necessary permissions were obtained from the teachers. Interviews were recorded as written and in audible.

Content analysis style, which is among qualitative data analysis techniques, were used in the analysis of the data. Accordingly, in order to reach meaningful patterns, after the interview transcripts were generated, codes were created by readings several times. Similar codes from the obtained codes were collected under the sub-themes. By examining sub-themes, the relevant subthemes were collected under themes. In the next stage, the findings obtained were defined and interpreted. Teachers' opinions are given by way of direct quotation. A researcher and a lecturer who is an expert in the field have coded the opinions of the teachers separately. The percentage of agreement formula (Reliability=Agreement/[Agreement+Disagreement] x100) suggested by Miles and Huberman (2016) was used by analyzing detected codes. As a result of the percent agreement formula, the opinion agreement rate among the coders was calculated to be .82 .

In the study, it was tested that there was no problem about the comprehensibility of the questions by conducting pilot interviews with two teachers for 30 minutes each. While creating the semistructured form, the relevant literature was examined and expert opinions were taken.

\section{Findings}

According to the findings obtained in the research; teachers working in state schools emphasized the sufficient physical conditions, low class size, lack of full day education, crowded classrooms, financial facilities, full day education, nutritional facilities and positive school climate for their preference of private school for their children regarding theme of organizational characteristics. According to results obtained from findings of research; teachers working in state schools emphasized, using of different methods and techniques, academic success, foreign language education, paid teachers, curriculum changes, curriculum, the opportunity to learn by doing and good/dedicated teacher staff for their preference of private school for their children regarding education teaching theme. According to results obtained from findings of research; teachers working in state schools emphasized, educated/conscious parents, cosmopolitan structure of public schools, environment and safe school environment for their preference of private school for their children regarding environmental features theme.

\section{Discussion and Conclusion}

Research results reveals that the reasons why teachers prefer private schools for their children are associated with believing that their children receive a more qualified education in private schools, physical conditions provided by private schools, technological opportunities, devotion of 
teachers, school environment, sports activities, academic success, using of different methods and techniques in teaching, foreign language education and positive school climate.

The following recommendations can be made in the context of the results obtained from the research:

1. More qualified in-service trainings that enable the personal and professional development of teachers working in public schools can be included.

2. Incentive measures can be taken to reduce the demands of teachers for relocation.

3. In state schools, efforts can be made to increase the performance of teachers and students by keeping the class sizes at a minimum.

4. In state schools, school cafeterias can be provided to serve by taking into account the nutritional needs of students in accordance with their physical and mental development.

5. Considering the difficulties students experience in transportation to school, necessary precautions can be taken.

6. Establishment of materials, workshops and laboratories that provide students with learning opportunities by doing and living in state schools and physical opportunities that will contribute to their social, sportive and cultural development can be provided.

7. In future studies, interviews can be conducted with teachers' spouses and children. In addition to interviews, observations can be made in school settings.

\section{Etik Kurul İzin:}

Yapılan bu çalışmada "Yükseköğretim Kurumları Bilimsel Araştırma ve Yayın Etiği Yönergesi" kapsamında uyulması belirtilen tüm kurallara uyulmuştur. Bu çalışma için etik kurul izni Düzce Üniversitesi Bilimsel Araştırma ve Yayın Etik Kurulu'nun 24.06.2021 tarihli ve 2021/160 numaralı kararı ile alınmıştır. 